\title{
Calculating Contained Firing Facility (CFF) Explosive Firing Zones
}

J. W. Lyle

February 15, 2001

U.S. Department of Energy

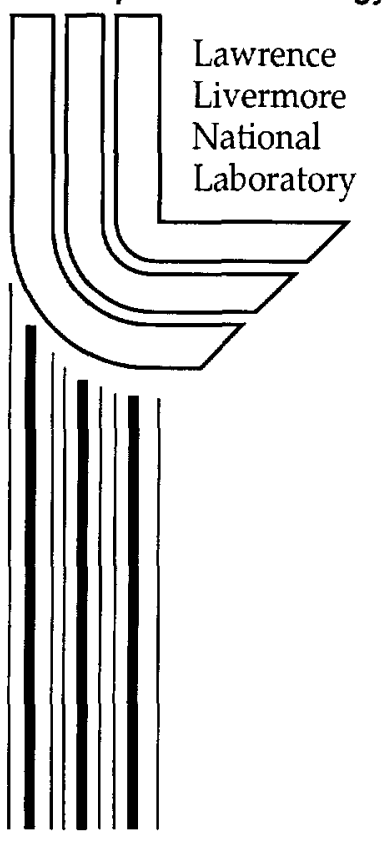




\section{DISCLAIMER}

This document was prepared as an account of work sponsored by an agency of the United States Government. Neither the United States Government nor the University of California nor any of their employees, makes any warranty, express or implied, or assumes any legal liability or responsibility for the accuracy, completeness, or usefulness of any information, apparatus, product, or process disclosed, or represents that its use would not infringe privately owned rights. Reference herein to any specific commercial product, process, or service by trade name, trademark, manufacturer, or otherwise, does not necessarily constitute or imply its endorsement, recommendation, or favoring by the United States Government or the University of California. The views and opinions of authors expressed herein do not necessarily state or reflect those of the United States Government or the University of California, and shall not be used for advertising or product endorsement purposes.

This work was performed under the auspices of the U. S. Department of Energy by the University of California, Lawrence Livermore National Laboratory under Contract No. W-7405-Eng-48.

This report has been reproduced directly from the best available copy.

Available electronically at http://www.doc.gov/bridge

Available for a processing fee to U.S. Department of Energy

And its contractors in paper from

U.S. Department of Energy

Office of Scientific and Technical Information

P.O. Box 62

Oak Ridge, TN 37831-0062

Telephone: (865) 576-8401

Facsimile: (865) 576-5728

E-mail: reports@adonis.osti.gov

Available for the sale to the public from

U.S. Department of Commerce

National Technical Information Service 5285 Port Royal Road

Springfield, VA 22161

Telephone: (800) 553-6847

Facsimile: (703) 605-6900

E-mail: orders@ntis.fedworld.gov

Online ordering: http://www.ntis.gov/ordering.htm

\section{OR}

Lawrence Livermore National Laboratory

Technical Information Department's Digital Library

http://www.llnl.gov/tid/Library.html 


\title{
CALCULATING CONTAINED FIRING FACILITY (CFF) EXPLOSIVE FIRING ZONES
}

\author{
J. W. Lyle \\ February 15,2001
}

\section{INTRODUCTION}

Revision 1 of this document presented a method of calculating the CFF explosive firing zones that was based upon the peak average pressure on the various elements of the firing chamber as explosive weights and locations are changed. That document (Reference 1) was reviewed internally at LLNL (Reference 2) and reviewed by the design contractor of the facility (References 3 and 4). The contractor's responses generally confirmed the validity of the peak average pressure method, but noted that the shearing stresses at haunches may exceed the design values when explosive charges are moved towards corners.

The concept of a dynamic load factor is introduced in the dynamic analysis section of Reference 5. A method is shown there whereby the response of the major elements of construction can be calculated from the knowledge of the peak average blast pressure averaged over the surface considered, the length of the pulse, and the natural period of vibration of the element. Quazi Hossain also suggested this method of analysis in Reference 2.

The major elements of the Firing Chamber are the four walls, floor, roof slab, camera room overlay structure, inclined plate, bullnose, and the two doors. Except for the bullnose, their response has been calculated for a number of explosive weights and locations and compared with the design calculations. This has led to a more conservative drawing of the firing zones. As suggested by the contractor the shearing stresses at a wall-haunch corner were calculated as a function of charge location and compared with the design calculations.

\section{BACKGROUND}

The University awarded a contract for the design of the Contained Firing Facility (CFF) to Parsons Infrastructure \& Technology, Inc. of Pasadena, California. The Laboratory specified that the firing chamber be able to withstand repeated firings of $206.3 \mathrm{lbs}$. of TNT located in the center of the chamber, 4 feet above the floor, and repeated firings of $120.3 \mathrm{lbs}$. of TNT at the same height and located anywhere within 2 feet of the edge of a region on the floor called the anvil. Other requirements were that the chamber be able to accommodate the penetrations of the existing bullnose of the Bunker 801 flash X-ray machine, the roof and north wall of the existing underground camera room. and have two 
blast resistant doors. It is anticipated that a great variety of explosive configurations will be detonated in the chamber. Some of these experiments will have more than one explosive charge, and for reasons of optimum optical and electronic data collection, it will be necessary to locate the charges at points in the chamber that were not specifically considered by the designers. That is the rationale for these calculations, i.e. to answer the question: where can explosive charges be located so that the responses of all the major elements of construction do not exceed the design values?

The detailed calculations and specifications to achieve the design criteria were performed by Parsons and are included in Reference 6. The 12 page abstract in this Reference is especially valuable.

Reference 5, Structures to Resist the Effects of Accidental Explosions, (TM5-1300) is the primary design manual for structures of this type. It includes an analysis technique for the calculation of blast loadings within a cubicle or containment-type structure. Parsons used the TM5-1300 methods that are incorporated in the SHOCK code to calculate the loadings on the various firing chamber elements for the design criteria explosive weights and locations. At LLNL the same methods and code were used to calculate element loadings for a variety of other explosive weights and locations. TM5-1300 and the SHOCK code are written in the $\mathrm{lb}$-ft-millisecond system of units.

For the blast design of the firing chamber, the charge weights and locations were specified by LLNL in pounds of TNT prior to the initiation of the design work by Parsons. Because the Laboratory seldom uses charges of TNT, it is necessary to calculate the equivalency for a variety of plastic bonded explosives and other kinds of energetic materials. For its blast effects on structures, the equivalency of an explosive is the ratio of its heat of detonation to that of TNT. A ratio of 1.3 represents an average of the heats of detonation for a variety of explosives and this number was used to create the blast design requirements. In order to compensate for unknowns such as unexpected shock wave reflections, construction methods, quality of construction materials, etc. Reference 5 recommends that the TNT equivalent weight be increased by a factor of 1.2. This recommendation was adopted. The conceptual design of the facility chose the maximum weight of a generic explosive to be $60 \mathrm{Kg}$. Becoming a design requirement, $60 \mathrm{Kg}$ of a generic explosive was taken to be equivalent to $206.3 \mathrm{lbs}$. of TNT according to the following calculation: $60 \mathrm{Kg} \times 2.204 \mathrm{lbs} / \mathrm{Kg} \times 1.3 \times 1.2=206.3 \mathrm{lbs}$. Likewise for blast design purposes, $35 \mathrm{Kg}$ of generic explosive is equivalent to $120.3 \mathrm{lbs}$. of TNT.

\section{CALCULATIONAL PROCEDURE}

In section 2-14.2.1. of Reference 5, it is written:

"An approximate method for the calculation of the internal shock pressures has been developed using theoretical procedures based on semi-empirical blast data and on the results of response tests on slabs. The calculated average shock pressures have been compared with those obtained from the results of tests of a scale-model steel cubicle and have shown good agreement for a wide range of cubicle configurations. This method 
consists of the determination of the peak pressures and impulses acting at various points of each interior surface and then integrating to obtain the total shock load. In order to simplify the calculation of the response of a protective structure wall to these applied loads, the peak pressures and total impulses are assumed to be uniformly distributed on the surface. The peak average pressure and the total average impulse are given for any wall surface. The actual distribution of the blast loads is highly irregular, because of the multiple reflections and time phasing and results in localized high shear stresses in the element. The use of the average blast loads, when designing, is predicated on the ability of the element to transfer these localized loads to regions of lower stress. Reinforced concrete with properly designed shear reinforcement and steel plates exhibit this characteristic."

The procedure for the determination of the shock loads was programmed for solutions on a digital computer. The results are presented in Reference 5 on 96 figures. Fortunately, the text and figures of TM5-1300 are available as computer software that includes the means to read the graphical data. In this way it is easy to obtain peak reflected pressure, impulse, pulse length and other variables as a function of the scaled distance $\left(\mathrm{Z}=\mathrm{R} / \mathrm{W}^{\wedge} 1 / 3\right)$. In this expression, $\mathrm{R}$ is the distance from charge center to the surface in question and $\mathrm{W}$ is the weight of explosive in equivalent TNT pounds. The CFF firing chamber geometry is included in the range of the plotted variables so that extrapolation was not necessary, but interpolation between as many as 6 curves was required to fit some charge locations. The use of the SHOCK code greatly assists this process. Again from Reference 5, "The wall (if any) parallel and opposite to the surface in question has a negligible contribution to the shock loads for the range of parameters used and was therefore not considered."

The calculation of an element response begins with a choice of explosive weight and location. With these input variables, the SHOCK code provides the maximum average shock pressure (Pav) and the impulse duration of an assumed triangular blast load (Td) on the element. The natural period of vibration $(\mathrm{Tn})$ for each element was taken from either Reference 2 or 6 . The ratio $\mathrm{Td} / \mathrm{Tn}$ was then used with Figure 3-49 of Reference 5 to determine the dynamic load factor DLF. Alternatively, the following equation provides the DLF with a deviation from the graphed curve of Figure 3-49 that does not exceed $5 \%$.

$$
D L F=1.89285-1.89543 \times e^{-(1.89332) \times T_{d} / T_{n}}
$$

The response of the element $(\mathrm{rm})$ in pounds per square inch is found by multiplying the maximum average shock pressure by the dynamic load factor, thus: $\mathrm{rm}=\mathrm{Pav}$ x DLF.

\section{RESULTS FOR 4 FOOT EXPLOSIVE ELEVATION}

The governing or maximum calculated firing chamber major element responses are shown on Table 1. The locations and weights of explosive in pounds of equivalent TNT are those specified by the Laboratory, used by Parsons, and bound the design of the firing 
fi. lename: $\operatorname{sum} 20 . x 1 \mathrm{~s}$

Feb. 2, 2001

\section{Table 1}

CONTAINED FIRING FACILITY

MAXIMUM CALCULATED FIRING CHAMBER ELEMENT DESIGN RESPONSES

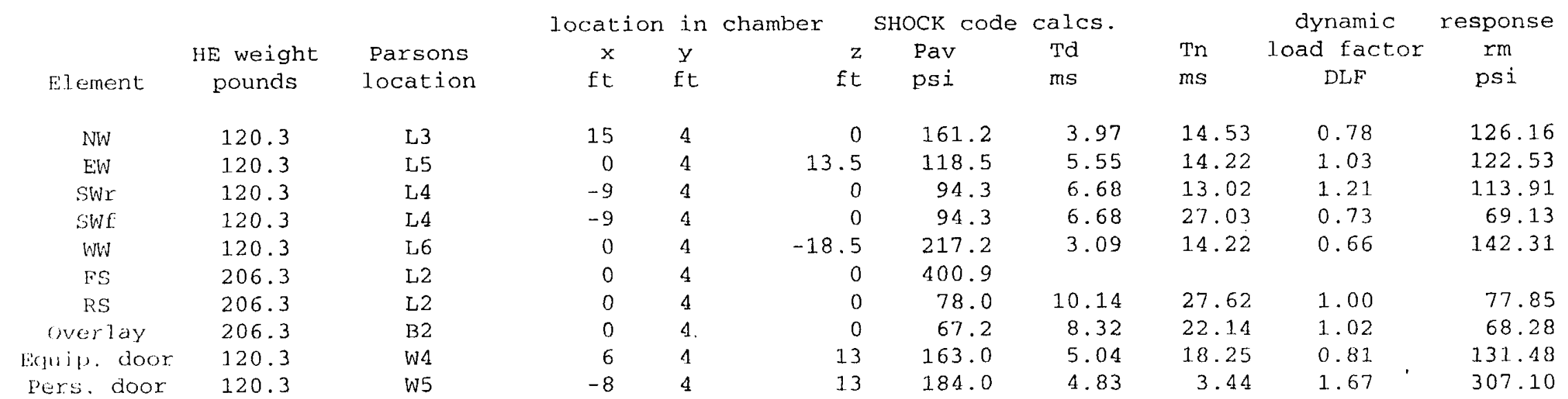

'lle roordinate system origin is on the floor at the center of the chamber.

Positive $(+x)$ is towards the north.

Positive $(+y)$ is towards the roof.

Positjue $(+z)$ is towards the east.

SW : ratifinued at the bottom

swl: live at the bottom

NW :- north wall, etc. 
chamber. The SHOCK code calculations are those done by Parsons and can be found in Reference 6. The determination of the dynamic load factors and the element responses proceeded from the Parsons calculations and was performed by the author.

A right-handed, orthogonal coordinate system was established to aid the understanding of the design effort and to facilitate the future location of experiments inside the firing chamber. The origin is at the center of the chamber floor, i.e. 27.5 feet from the east wall and 25.5 feet from the north wall. Positive $(+x)$ is towards the north, positive $(+y)$ is towards the roof, and positive $(+\mathrm{z})$ is towards the east.

Calculations for the west wall were performed as if no bullnose were present.

The base of the south wall is connected to the camera room overlay structure with a hinge-like system of pins-in-slots. Two calculations were performed for the south wall because its natural period of vibration is different depending if the bottom is restrained or free.

In order to avoid unknown close-in effects at the floor trench, the north 10 and $20 \mathrm{Kg}$ boundaries were made coincident with the $35 \mathrm{Kg}$ line.

The southern 40 and $50 \mathrm{Kg}$ boundaries were located such that the maximum average pressure and total average impulse on the inclined plate would be less than those calculated by Parsons for a $35 \mathrm{Kg}$ explosive, 2 feet inside the anvil edge, and symmetrically located with respect to the camera room porthole array. The $35 \mathrm{Kg}$ explosive causes higher forces on the inclined plate than the centered $60 \mathrm{Kg}$ explosive because its scaled distance $\mathrm{Z}$ is approximately $1 / 2$ that of the $60 \mathrm{Kg}$ charge.

The element response analysis for the floor slab is not applicable here because close-in effects dominate the phenomena. Reference 7 is applicable.

The precision of location in elevation is dependent upon the response of the roof slab and the shock behavior of the floor. For a constant explosive weight, an increase in elevation of 6 inches would increase the peak reflected pressure on the roof by $5 \%$ and is considered reasonable. A decrease in elevation of 0.125 inches would increase the peak reflected pressure on the floor by $5 \%$ and is considered reasonable.

Figure 1 is the map for the 4 foot explosive elevation. 


\section{Area descriptions for $\mathbf{4}$ foot explosive elevations:}

\section{$60 \mathrm{Kg}$ Area}

A rectangle, $2 \times 6$ feet, with its south east corner at the origin.

A combination of elastomeric materials, steel and aluminum plates has been constructed to attenuate the shocks driven into the floor slab. This square $8 \times 8$ foot assembly will be placed on the anvil under the explosive. Until the durability and usefulness of this "throw rug" has been proven, it seems prudent that the higher explosive weight experiments be moved no closer to the floor than 4 feet.

A $35 \mathrm{Kg}$ test at several locations within 2 feet of the anvil edge results in higher responses for the west and north walls than a $60 \mathrm{Kg}$ test at the origin. That is why the region for a $60 \mathrm{Kg}$ explosive is an area rather than a single point 4 feet above the origin. The response of the doors set into the east wall limit the approach in that direction.

\section{$50 \mathrm{Kg}$ Area}

A rectangle, $5.5 \times 16$ feet. The approach to the south is limited by the pressure and impulse delivered to the inclined plate.

\section{$40 \mathrm{Kg}$ Area}

A 5-sided polygon of the same general shape as the $35 \mathrm{Kg}$ area.

\section{$35 \mathrm{Kg}$ Area}

A 5-sided polygon located 2 feet inside the edge of the L-shaped region on the floor called the anvil. This configuration was a design requirement. The floor steel here is 4 inches thick, while outside the anvil it is 2 inches thick.

\section{$20 \mathrm{Kg}$ Area}

A rectangle, $23 \times 35$ feet.

\section{$10 \mathrm{Kg}$ Area}

A rectangle, $23 \times 37$ feet.

\section{$1.5 \mathrm{Kg}$ Area}

The $1.5 \mathrm{Kg}$ area is a trapezoid with its comers located over the centers of the four most widely separated optical portholes in the camera room. Its purpose is to accommodate as many as 10 distributed explosive pads that are used with glass turning mirrors. The present weight of these explosive "mirror pads" is 75 grams. but for some experiments 
the weight may be increased to no more than 150 grams. Operating experience with 75 gram mirror pads has shown that cracked porthole glasses may occur when the pads are placed closer than 18 inches to the glasses. It is likely that this critical distance will increase when larger explosive weights are used. With open air testing, this standoff distance was thought to be independent of the elevation of the main charge explosive. Multiple blast wave reflections in the firing chamber could substantially change the loading on the porthole glasses and cause them to crack.

\section{RESULTS FOR OTHER EXPLOSIVE ELEVATIONS}

Firing zone maps for elevations of 1, 2, 3, 3.5, 8, and 12 feet are figures 2-7.

For elevations less than 4 feet, it is the shock behavior of the floor that determines what weight of explosive can be detonated. These maps were calculated by keeping a constant scaled distance ( $Z=0.677$ for the $206.3 \mathrm{lb}$. TNT weight). The response of the other firing chamber elements would be little changed from what was calculated for the 4 foot elevation.

For elevations greater than 4 feet the responses of the roof slab, south wall, and overlay structure determine the maps. In general, the response of a wall-like element will be greatest when the charge is located in a symmetrical position, i.e. centered. With increased elevations, the angle between the overlay and the charge increases as does the blast loading on it. For the maps, as charges are elevated their weight is diminished by keeping the $\mathrm{Z}$ distance to the roof constant and the boundaries near the overlay structure move toward the north to maintain the maximum designed response of the overlay. This movement to accommodate the overlay is greater than that required to keep the response of the south wall at its maximum design value.

\section{SHEAR CALCULATIONS}

Shearing stress calculations began with a SHOCK code determination of the average shock pressure (Pav) on a reduced area of the north wall. The reduced area is a rectangle on the wall, normal to the charge, and extending to the west as far as the haunch and bounded by the roof haunch and the floor slab. The total force on the reduced area is obtained by multiplying the average pressure Pav by the area. The result is then divided by the sum of the three areas A1, A2, and A3 that are normal to the reduced area and which connect it to the balance of the wall, and to the roof and floor slabs. A pressure proportional to the shearing stress is obtained in this way. The calculation was done for the nearest 206.3 pound charge and for a 120.3 pound charge as a function of the location variable $z$. It was determined that the highest shearing stresses in the north wall will occur for a 120.3 pound charge placed on the anvil at the governing design location $\mathrm{x}=$ $17, y=4, z=-3.5 \mathrm{ft}$. Similar calculations were made for the north wall for other proposed charge weights and locations to ensure that the shearing stresses would be less than those calculated for the governing case. 


\section{TYPICAL SHOT CONFIGURATIONS}

Upon initial operation, the maximum total generic high explosive charge will be limited to $60 \mathrm{Kg}$. Management may wish to amend this requirement after the initial testing of the firing chamber is accomplished and when sufficient operating experience has been accumulated.

A single bare or cased explosive charge can be placed anywhere within the firing zone appropriate to its weight. Permissible locations for single charge intermediate weights can be determined by simple linear interpolation between the several maps.

For optical diagnostics, a typical shot consists of a main charge and four explosivelydriven illuminating "candles" of $1.8 \mathrm{Kg}$ charge weight each. Again, the total weight of the distributed explosives, including the optical porthole mirror pads, may not exceed 60 $\mathrm{Kg}$. The weight of the main charge will determine the appropriate firing zone. However, in the absence of any attenuating provisions, and in order not to exceed the design pressure on the floor, the $1.8 \mathrm{Kg}$ candles may be placed no closer than 13 to 14 inches from the floor.

Multiple explosive charges, split charges, and shaped charges present unusual shot setup configuration requirements. Care must be taken not only to limit the blast pressures on the firing chamber elements but also to protect the structures from high velocity jets. Part of management's shot approval process includes a peer review panel. Experiments of the type considered in this paragraph will be submitted to the panel for further analysis and approval.

\section{CONCLUSIONS}

The firing zone maps are meant to be used by ramrods, physicists, engineers, and bunker personnel for the safe placement of explosives in the facility. The objective is to maintain a minimum safety factor of 1.7 to the elastic limit for the most heavily stressed chamber element. It is important to point out that the zones are based solely on calculations with the assumption that the firing chamber will meet its design objectives. The firing chamber will be fitted with gauges to measure strain. As testing and operating experience are accumulated, the map profiles may be adjusted. In addition, deviations from these maps are possible with appropriate analyses, approval and planning, and through the use of blast attenuation and mitigation measures.

The most heavily stressed element in the firing chamber will be the floor. Various configurations of attenuating materials have been tested that minimize blast damage to the floors of explosive testing chambers. Some examples can be found in Reference 8 . Additional experimental studies have been conducted towards the design of an attenuating system for use in the firing chamber. Our intention is to use such a system until experience shows that it may not be necessary. 


\section{REFERENCES}

1. J. W. Lyle, Calculating Contained Firing Facility (CFF) Explosive Firing Zones, Lawrence Livermore National Laboratory, Livermore CA 94550, UCRL-ID132204 Rev 1, February 3, 1999.

2. Quazi A. Hossain, Review of Parsons' Design and Analysis of LLNL'S Site 300 Contained Firing Facility Chamber Structures, New Technology Engineering Division, Lawrence Livermore National Laboratory, Livermore CA 94550 , CFF/SF00-025, April 7, 2000.

3. Henry Ayvazyan, Response to RFI 003 LLNL/CFF CHAMBER, Parsons Infrastructure \& Technology, Inc., Pasadena, CA, 07 February, 2000.

4. Henry Ayvazyan, Response to RF1 004 LLNL/CFF Chamber, Parsons Infrastructure \& Technology, Inc., Pasadena, CA 10 February, 2000.

5. Departments of the Army, Navy, and Air Force, Structures to Resist the Effects of Accidental Explosions, Army TM5-1300, Headquarters, Washington, D.C. 19 November 1990.

6. Site 300, Contained Firing Facility, Final Structural Chamber Calculations, LLNL Contract No. B345381, Parsons Job No. 732925, May 29, 1998.

7. Mark L. Wilkins, Shock Hydrodynamics, Lawrence Livermore National Laboratory, Livermore, CA 94550, UCRL-6797, February 19, 1962.

8. J. W. Pastrnak, C. F. Baker, and L. F. Simmons. Quarter-Scale Close-in BlastLoading Experiments in Support of the Planned Contained Firing Facility, Lawrence Livermore National Laboratory, Livermore, California, UCRL-JC-116822, July 27, 1994. 


\section{Appendix A}

Appendix A copies the design and response calculations from Table 1 for comparison with similar calculations that were done to create the firing zone maps. 


\section{Appendix A}

CONTAINED FIRING FACILITY

SUMMARY OF SHOCK CODE AND ELEMENT RESPONSE CALCULATIONS

$\begin{array}{ccccccccc}\begin{array}{c}\text { distance } \\ \text { to }\end{array} & & \text { location } & & & & & \text { reponse } \\ \text { element } & x & y & z & \text { Pav } & \text { td } & \text { tn } & & \text { rm } \\ \text { ft } & f t & \mathrm{ft} & \mathrm{ft} & \text { psi } & \mathrm{ms} & \mathrm{ms} & \text { DLF } & \text { psi }\end{array}$

\begin{tabular}{|c|c|c|c|c|c|c|c|c|c|c|c|}
\hline \multicolumn{12}{|c|}{ Parsons design calculations, (governing) } \\
\hline $\mathrm{P}^{2}$ & 120.3 & NW & 10.5 & 15 & 4 & 0 & 161.2 & 3.97 & 14.53 & 0.78 & 126.16 \\
\hline P2 & 120.3 & EW & 14.0 & 0 & 4 & 13.5 & 118.5 & 5.55 & 14.22 & 1.03 & 122.53 \\
\hline 13 & 120.3 & SWr & 16.5 & -9 & 4 & 0 & 94.3 & 6.68 & 13.02 & 1.21 & 113.91 \\
\hline 144 & 120.3 & SWE & 16.5 & -9 & 4 & 0 & 94.3 & 6.68 & 27.03 & 0.73 & 69.13 \\
\hline pb & 120.3 & WW & 9.0 & 0 & 4 & -18.5 & 217.2 & 3.09 & 14.22 & 0.66 & 142.31 \\
\hline 56 & 206.3 & FS & 4.0 & 0 & 4 & 0 & 400.9 & \multicolumn{4}{|c|}{ Not applicable } \\
\hline E'7 & 206.3 & RS & 26.0 & 0 & 4 & 0 & 78.0 & 10.14 & 27.62 & 1.00 & 77.85 \\
\hline 13:? & 206.3 & overlay & 1.7 & 0 & 4 & 0 & 67.2 & 8.32 & 22.14 & 1.02 & 68.28 \\
\hline W & 120.3 & Equip. Dr. & 18.5 & 6 & 4 & 13 & 163.0 & 5.04 & 18.25 & 0.81 & 131.48 \\
\hline Wh & 120.3 & Pers. Dr & 1.8 .5 & -8 & 4 & 13 & .184 .0 & 4.83 & 3.44 & 1.67 & 307.10 \\
\hline \multicolumn{12}{|c|}{ l.Lnl calculations } \\
\hline $\mathrm{C} 1$ & 120.3 & NW & 8.5 & 17 & 4 & -18.5 & 202.6 & 3.11 & 14.53 & 0.63 & 127.39 \\
\hline 62 & 120.3 & NW & 8.5 & 17 & 4 & -3.5 & 220.4 & 2.93 & 14.53 & 0.60 & 131.97 \\
\hline$c 3$ & 120.3 & NW & 19.5 & 6 & 4 & -3.5 & 77.1 & 8.09 & 14.53 & 1.27 & 97.53 \\
\hline 110 & 120.3 & $\mathrm{NW}$ & 8.5 & 17 & 4 & -11.5 & 216.3 & 2.96 & 14.53 & 0.60 & 130.61 \\
\hline $13 \% .3$ & 137.3 & NW & 20.5 & 5 & 4 & 0 & 81.0 & 8.40 & 14.53 & 1.26 & 101.92 \\
\hline 11 & 137.3 & $\mathrm{NW}$ & 10.5 & 15 & 4 & -11.5 & 178.1 & 3.89 & 14.53 & 0.75 & 133.74 \\
\hline $1: 12$ & 137.3 & NW & 12.5 & 13 & 4 & -11.5 & 139.7 & 4.34 & 14.53 & 0.90 & 1.25 .11 \\
\hline F13 & 137.3 & $\mathrm{NW}$ & 14.5 & 11 & 4 & -11.5 & 114.7 & 5.98 & 14.53 & 1.02 & 117.35 \\
\hline F14 & 1.37 .3 & NW & 16.5 & 9 & 4 & -11.5 & 99.9 & 6.94 & 14.53 & 1.13 & 112.42 \\
\hline 171.6 & 171.6 & NW & 22 & 3.5 & 4 & 0 & 88.3 & 8.90 & 14.53 & 1.30 & 114.64 \\
\hline F15 & 171.6 & NW & 12.5 & 13 & 4 & -11.5 & 172.5 & 4.63 & 14.53 & 0.86 & 147.63 \\
\hline r16 & 171.6 & NW & 14.5 & 11 & 4 & -11.5 & 138.5 & 5.72 & 14.53 & 0.99 & 137.55 \\
\hline$F 1 \%$ & 17.1 .6 & NW & 16.5 & 9 & 1 & -1.1 .5 & 119.4 & 6.71 & 3.4 .53 & 1.10 & 131.57 \\
\hline 18 & $1 \% .6$ & NW & 18.5 & 7 & 4 & -11.5 & 103.7 & 7.63 & 14.53 & 1.19 & 123.54 \\
\hline DI & 206.3 & NW & 10 & 15.5 & 4 & -18.5 & 267.2 & 3.42 & 14.53 & 0.68 & 181.38 \\
\hline D2 & 206.3 & NW & 10 & 15.5 & 4 & -1.5 .5 & 282.6 & 3.20 & 14.53 & 0.64 & 181.86 \\
\hline 123 & 206.3 & NW & 10 & 15.5 & 4 & -12.5 & 289.6 & 3.14 & 14.53 & 0.63 & 183.52 \\
\hline DA & 206.3 & NW & 10 & 15.5 & 4 & -9.5 & 293.6 & 3.12 & 14.53 & 0.63 & 185.09 \\
\hline 105 & 206.3 & NW & 10 & 15.5 & 4 & -6.5 & 296.3 & 3.11 & 14.53 & 0.63 & 186.31 \\
\hline D6 & 206.3 & NW & 10 & 15.5 & 4 & -3.5 & 297.9 & 3.10 & 14.53 & 0.63 & 186.82 \\
\hline D7 & 206.3 & $\mathrm{NW}$ & 12 & 13.5 & 4 & -18.5 & 196.1 & 4.58 & 14.53 & 0.85 & 166.50 \\
\hline 1$) 8$ & 206.3 & NW & 12 & 13.5 & 4 & -15.5 & 208.7 & 4.38 & 14.53 & 0.82 & 171.45 \\
\hline 19 & 206.3 & $\mathrm{NW}$ & 12 & 13.5 & 4 & -12.5 & 215.8 & 4.19 & 14.53 & 0.79 & 171.49 \\
\hline
\end{tabular}




\begin{tabular}{|c|c|c|c|c|c|c|c|c|c|c|c|}
\hline run & $\begin{array}{c}\text { TNT } \\
\text { weight } \\
\text { lbs. }\end{array}$ & element & $\begin{array}{c}\text { distance } \\
\text { to } \\
\text { element } \\
\mathrm{ft}\end{array}$ & $\begin{array}{c}x \\
f t\end{array}$ & $\begin{array}{l}\text { fation } \\
y \\
\text { ft }\end{array}$ & $\begin{array}{c}z \\
f t\end{array}$ & $\begin{array}{l}\text { Pav } \\
\text { psi }\end{array}$ & $\begin{array}{l}\text { td } \\
\text { ms }\end{array}$ & $\begin{array}{l}\mathrm{tn} \\
\mathrm{ms}\end{array}$ & DIF & $\begin{array}{c}\text { reponse } \\
\text { rm } \\
\text { psi }\end{array}$ \\
\hline D10 & 206.3 & NW & 12 & 13.5 & 4 & -9.5 & 219.9 & 4.14 & 14.53 & 0.79 & 173.17 \\
\hline D1 1 & 206.3 & $\mathrm{NW}$ & 12 & 13.5 & 4 & -6.5 & 222.6 & 4.10 & 14.53 & 0.78 & 174.01 \\
\hline D12 & 206.3 & $\mathrm{NW}$ & 12 & 13.5 & 4 & -3.5 & 224.1 & 4.08 & 14.53 & 0.78 & 174.53 \\
\hline D 13 & 206.3 & NW & 14 & 11.5 & 4 & -18.5 & 154.6 & 5.72 & 14.53 & 0.99 & 153.53 \\
\hline D1.4 & 206.3 & NW & 14 & 11.5 & 4 & -15.5 & 165.3 & 5.44 & 14.53 & 0.96 & 158.64 \\
\hline DJ1 5 & 206.3 & $\mathrm{NW}$ & 14 & 11.5 & 4 & -12.5 & 172.6 & 5.19 & 14.53 & 0.93 & 160.31 \\
\hline D) 6 & 206.3 & NW & 14 & 11.5 & 4 & -9.5 & 176.7 & 5.09 & 14.53 & 0.92 & 161.88 \\
\hline D17 & 206.3 & $\mathrm{NW}$ & 14 & 11.5 & 4 & -6.5 & 179.1 & 5.04 & 14.53 & 0.91 & 162.94 \\
\hline D) 8 & 206.3 & NW & 14 & 11.5 & 4 & -3.5 & 180.5 & 5.01 & 14.53 & 0.91 & 163.52 \\
\hline D19 & 206.3 & NW & 18 & 7.5 & 4 & -11 & 125.8 & 7.14 & 14.53 & 1.15 & 144.05 \\
\hline n20 & 206.3 & NW & 20 & 5.5 & 4 & -11 & 109.5 & 8.09 & 14.53 & 1.23 & 134.91 \\
\hline 121 & 206.3 & $\mathrm{NW}$ & 22 & 3.5 & 4 & -11 & 95.3 & 9.28 & 14.53 & 1.33 & 126.16 \\
\hline $12 \%$ & 206.3 & NW & 21 & 4.5 & 4 & -11 & 101.9 & 8.64 & 14.53 & 1.28 & 130.2 \\
\hline 524 & 206.3 & NW & 22 & 3.5 & 4 & -6 & 100.2 & 8.94 & 14.53 & 1.30 & 130.39 \\
\hline Fi & 206.3 & $\mathrm{NW}$ & 25.5 & 0 & 4 & 0 & 88.7 & 10.17 & 14.53 & 1.39 & 123.2 \\
\hline$r a$ & 206.3 & NW & 23.5 & 2 & 4 & 0) & 94.9 & 9.31 & 14.53 & 1.33 & 126.35 \\
\hline F3 & 206.3 & NW & 21.5 & 4 & 4 & 0 & 105.1 & 8.42 & 14.53 & 1.26 & 132.41 \\
\hline F4 & 206.3 & NW & 19.5 & 6 & 4 & 0 & 120.1 & 7.40 & 14.53 & 1. 17 & 140.51 \\
\hline Fis & 206.3 & NW & 17.5 & 8 & 4 & 0 & 136.2 & 6.57 & 14.53 & 1.09 & 148.11 \\
\hline 56 & 206.3 & $\mathrm{NW}$ & 15.5 & 10 & 4 & 0 & 155.8 & 5.76 & 14.53 & 1.00 & 155.45 \\
\hline F7 & 206.3 & NW & 13.5 & 12 & 4 & 0 & 190.7 & 4.77 & 1.4 .53 & 0.87 & 166.78 \\
\hline F8 & 206.3 & NW & 11.5 & 14 & 4 & 0 & 240.2 & 3.83 & 14.53 & 0.74 & 178.22 \\
\hline Fy & 206.3 & NW & 9.5 & 16 & 4 & ) & 318.9 & 2.90 & 14.53 & 0.59 & 189.34 \\
\hline$F 10$ & 171.6 & NW & 22 & 3.5 & 4 & 0 & 88.3 & 8.90 & 14.53 & 1.30 & 114.65 \\
\hline F 11 & 137.3 & $N W$ & 20.5 & 5 & 4 & 0 & 81.0 & 8.40 & 14.53 & 1.26 & 101.93 \\
\hline $\mathrm{C} 4$ & 120.3 & $\mathrm{EW}$ & 13 & 19.5 & 4 & 14.5 & 127.0 & 5.17 & 14.22 & 0.94 & 119.46 \\
\hline $\mathrm{C} 5$ & 120.3 & EW & 13 & -1 & 4 & 14.5 & 128.4 & 5.13 & 14.22 & 0.94 & 120.13 \\
\hline C6 & 120.3 & EW & 13 & -6 & 4 & 14.5 & 127.0 & 5.17 & 14.22 & 0.94 & 119.46 \\
\hline E1 & 206.3 & EW & 25.5 & -2 & 4 & 2 & 91.5 & 10.36 & 14.22 & 1.42 & 129.54 \\
\hline $\mathrm{E} 2$ & 206.3 & E:W & 23.5 & -2 & 4 & 4 & 98.5 & 9.55 & 14.22 & 1.36 & 134.1 \\
\hline E3 & 206.3 & EW & 21.5 & -2 & 4 & 6 & 110.0 & 8.37 & 14.22 & 1.27 & 139.81 \\
\hline :A & 206.3 & lsw & 19.5 & -2 & 4 & 8 & 126.2 & 7.31 & 14.22 & 1.18 & 148.5. \\
\hline l:b & 206.3 & $\mathrm{EW}$ & 17.5 & -2 & 4 & 10 & 143.7 & 6.47 & 14.22 & 1.09 & 156.92 \\
\hline E6 & 206.3 & EW & 15.5 & -2 & 4 & 12 & 164.9 & 5.66 & 14.22 & 1.00 & 165.03 \\
\hline E7 & 171.6 & $\mathrm{EW}$ & 25.5 & 0 & 4 & 2 & 79.0 & 10.99 & 14.22 & 1.45 & 114.88 \\
\hline E8 & 171.6 & EW & 23.5 & 0 & 4 & 4 & 86.0 & 9.60 & 14.22 & 1.36 & 117.39 \\
\hline E9 & 171.6 & EW & 21.5 & 0 & 4 & 6 & 94.8 & 8.61 & 14.22 & 1.29 & 122.35 \\
\hline E10 & 171.6 & EW & 19.5 & 0 & 4 & 8 & 108.1 & 6.58 & 14.22 & 1.20 & 129.94 \\
\hline ti1 & $13 \% .3$ & EW & 23.5 & 0 & 4 & 4 & 72.6 & 9.88 & 14.22 & 1.38 & 100.5 \\
\hline 112 & 137.3 & EW & 21.5 & 0 & 4 & 6 & 80.3 & 8.83 & 14.22 & 1.31 & 105.03 \\
\hline 113 & 137.3 & $\mathrm{EW}$ & 19.5 & 0 & 4 & 8 & 89.8 & 7.89 & 14.22 & 1.23 & 110.45 \\
\hline E1 4 & 137.3 & EW & 17.5 & 0 & 4 & 10 & 103.2 & 6.87 & 14.22 & 1.13 & 116.98 \\
\hline E15 & 137.3 & EW & 15.5 & 0 & 4 & 12 & 118.9 & 6.01 & 14.22 & 1.04 & 123.82 \\
\hline
\end{tabular}


distance

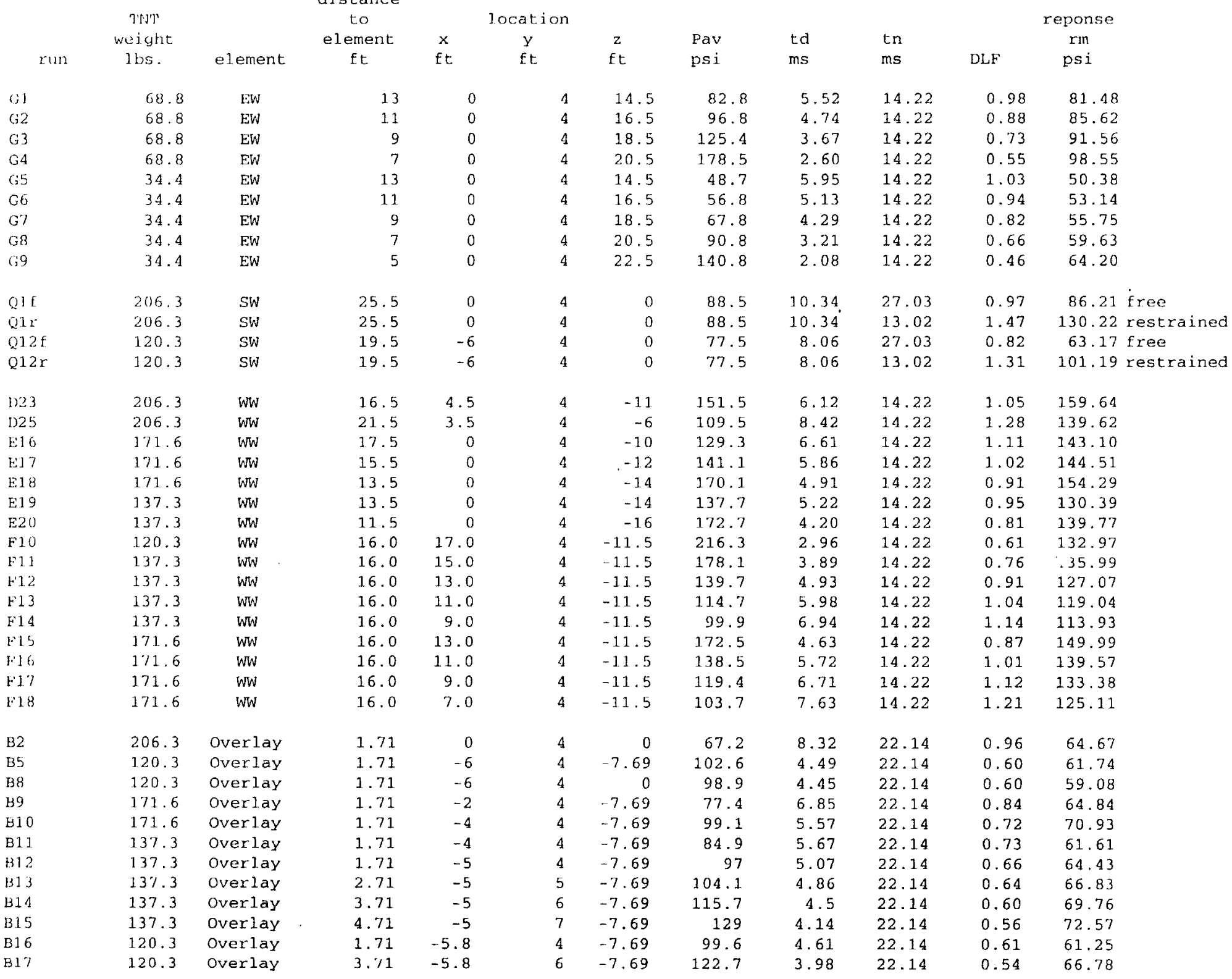




\begin{tabular}{|c|c|c|c|c|c|c|c|c|c|c|c|}
\hline run & $\begin{array}{c}\text { TNT } \\
\text { weight } \\
\text { lbs. }\end{array}$ & element & $\begin{array}{c}\text { distance } \\
\text { to } \\
\text { element } \\
\text { ft }\end{array}$ & $\begin{array}{c}x \\
f t\end{array}$ & $\begin{array}{l}\text { cation } \\
y \\
\text { ft }\end{array}$ & $\begin{array}{c}z \\
f t\end{array}$ & $\begin{array}{l}\text { Pav } \\
\text { psi }\end{array}$ & $\begin{array}{l}\mathrm{td} \\
\mathrm{mS}\end{array}$ & $\begin{array}{l}\mathrm{tn} \\
\mathrm{mS}\end{array}$ & DLF & $\begin{array}{c}\text { reponse } \\
\text { rm } \\
\text { psi }\end{array}$ \\
\hline$B 18$ & 120.3 & Overlay & 5.71 & -5.8 & 8 & -7.69 & 148.1 & 3.47 & 22.14 & 0.48 & 71.70 \\
\hline B19 & 120.3 & overlay & 7.71 & -5.8 & 10 & -7.69 & 147.6 & 3.58 & 22.14 & 0.50 & 73.40 \\
\hline B20 & 120.3 & Overlay & 9.71 & -5.8 & 12 & -7.69 & 132.3 & 4.07 & 22.14 & 0.55 & 73.37 \\
\hline B21. & 120.3 & Overlay & 11.71 & -5.8 & 14 & -7.69 & 120.8 & 4.53 & 22.14 & 0.61 & 73.23 \\
\hline $\mathrm{B} 22$ & 120.3 & Overlay & 13.71 & -5.8 & 16 & -7.69 & 112.5 & 4.93 & 22.14 & 0.65 & 73.07 \\
\hline B23 & 120.3 & Overlay & 3.71 & -4.8 & 6 & -7.69 & 101.3 & 4.70 & 22.14 & 0.62 & 63.29 \\
\hline B2A & 120.3 & Overlay & 3.71 & -3.8 & 6 & -7.69 & 85.7 & 5.40 & 22.14 & 0.70 & 59.86 \\
\hline 125 & 120.3 & Overlay & 3.71 & -2.8 & 6 & -7.69 & 73.7 & 6.12 & 22.14 & 0.77 & 56.73 \\
\hline B26 & 120.3 & Overlay & 3.71 & -1.8 & 6 & -7.69 & 63.7 & 6.90 & 22.14 & 0.84 & 53.65 \\
\hline B27 & 120.3 & Overlay & 9.71 & -4.8 & 12 & -7.69 & 112.3 & 4.65 & 22.14 & 0.62 & 69.55 \\
\hline B28 & 120.3 & Overlay & 9.71 & -3.8 & 12 & -7.69 & 95.1 & 5.34 & 22.14 & 0.69 & 65.84 \\
\hline B2.9 & 120.3 & Overlay & 9.71 & -2.8 & 12 & -7.69 & 81.0 & 6.10 & 22.14 & 0.77 & 62.20 \\
\hline B30 & 1.20 .3 & Overlay & 9.71 & -1.8 & 12 & -7.69 & 70.3 & 6.87 & 22.14 & 0.84 & 59.02 \\
\hline B31 & 137.5 & Overlay & 5.71 & -2.3 & 8 & -7.69 & 80.9 & 6.23 & 22.14 & 0.78 & 63.13 \\
\hline $\mathrm{B3} 2$ & 68.46 & Overlay & 9.71 & -2.3 & 12 & -7.69 & 47.9 & 7.06 & 22.14 & 0.86 & 41.03 \\
\hline H1 & 68.8 & Equip. door & 16.5 & 6 & 4 & 11 & 127.1 & 4.58 & 18.25 & 0.71 & 90.78 \\
\hline $\mathrm{H}_{2}$ & 68.8 & Equip. door & 16.5 & 8 & 4 & 11 & 138.7 & 4.49 & 18.25 & 0.70 & 97.53 \\
\hline 113 & 68.8 & Equip. door & 16.5 & 1.0 & 4 & 11 & 148.9 & 4.53 & 18.25 & 0.71 & 105.44 \\
\hline $\mathrm{HA}$ & 68.8 & Equip. door & 16.5 & 12 & 4 & 11 & 156.0 & 4.44 & 18.25 & 0.70 & 108.73 \\
\hline HS & 68.8 & Equip. door & 16.5 & 14 & 4 & 11 & 159.0 & 4.42 & 18.25 & 0.69 & 110.43 \\
\hline н6 & 68.8 & Equip. door & 16.5 & 16 & 4 & 11. & 157.5 & 4.48 & 18.25 & 0.70 & 110.55 \\
\hline 17 & 68.8 & Equip. door & 16.5 & 18 & 4 & 11 & 151.7 & 4.63 & 18.25 & 0.72 & 109.27 \\
\hline H8 & 34.4 & Equip. door & 14.5 & 6 & 4 & 13 & 88.3 & 4.30 & 18.25 & 0.68 & 60.00 \\
\hline 119 & 34.4 & Equip. door & 14.5 & 8 & 4 & 13 & 100.6 & 4.02 & 18.25 & 0.64 & 64.76 \\
\hline 1110 & 34.4 & Equip. door & 14.5 & 10 & 4 & 13 & 111.7 & 3.88 & 18.25 & 0.63 & 69.86 \\
\hline 1111 & 34.1 & Liquip. Goor & 14.5 & 12 & 4 & 13 & 119.5 & 3.92 & 18.25 & 0.63 & 75.37 \\
\hline 112 & 34.4 & Equip. door & 14.5 & 14 & 4 & 13 & 122.8 & 3.88 & 18.25 & 0.63 & 76.81 \\
\hline H13 & 34.4 & Equip. door & 14.5 & 16 & 4 & 13 & 121.1 & 3.94 & 18.25 & 0.63 & 76.70 \\
\hline H14 & 34.4 & Equip. door & 14.5 & 18 & 4 & 13 & 114.8 & 4.11 & 18.25 & 0.66 & 75.23 \\
\hline
\end{tabular}




\section{Appendix B}

Appendix B copies part of the Parsons calculations that were made to design the inclined plate (Reference 6). The calculations at LLNL were done to locate the 40 and $50 \mathrm{Kg}$ southern boundaries. The criteria was to not exceed the Pav that was calculated for the $35 \mathrm{Kg}$ charge. Use of the reduced area feature of the SHOCK code resulted in the 4 sets of values for each explosive weight. For the 40 and $50 \mathrm{Kg}$ weights, the maximum Pav is less than the design values for the closer-in $35 \mathrm{Kg}$ charge. For three of the calculations the calculated impulse was as much as $6 \%$ higher than that calculated for the $35 \mathrm{Kg}$ charge. 
filename: $\operatorname{sum} 7 . x 1 \mathrm{~s}$

\section{APPENDIX B}

CFF SHOCK CODE SUMMARY \#7, INCLINED PLATE DESIGN PRESSURES, IMPULSES, AND DURATION 4 FOOT SHOT ELEVATION, ON LINE BISECTING PORTHOLE 7-FP

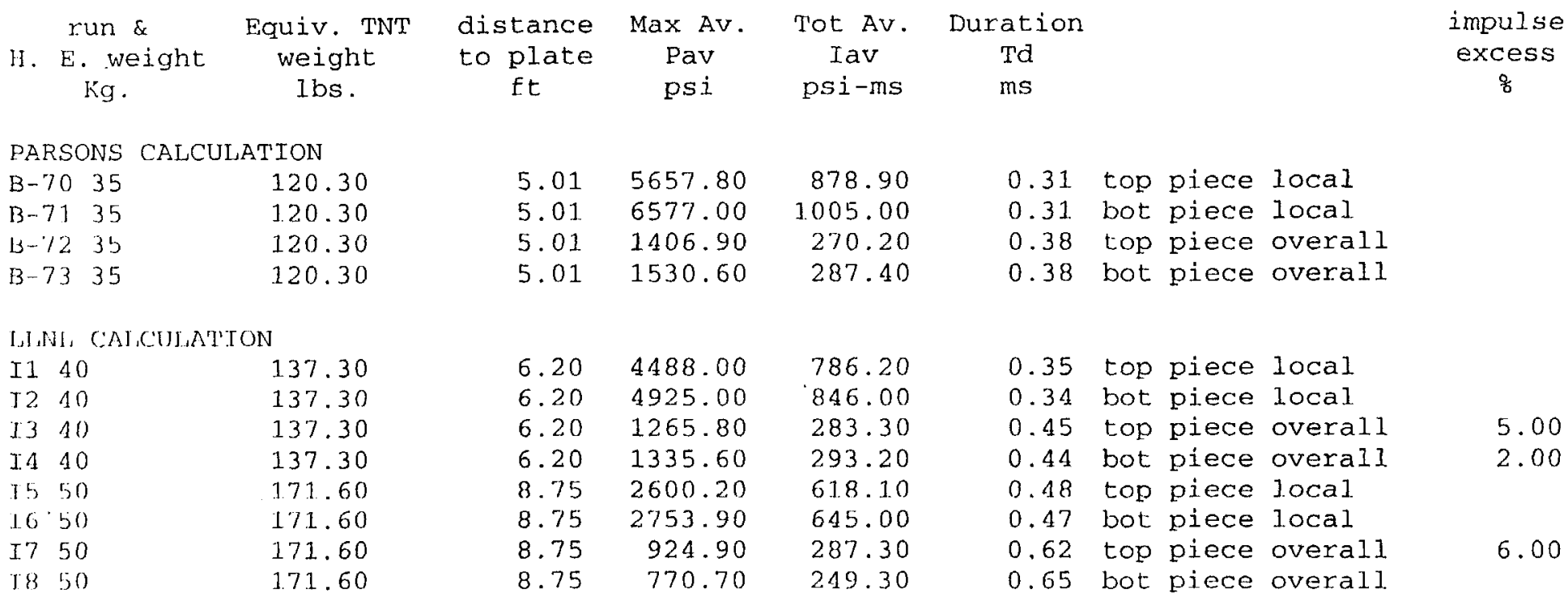




\section{Appendix C}

Appendix $\mathrm{C}$ presents the results of the shear stress calculations for the north wall. 
filename: sum5.xls

\section{Appendix C}

CFF SHOCK CODE SUMMARY \#5, NORTH WALL SHEAR CALCULATIONS

4 FEET ABOVE THE FLOOR REDUCED AREA AT WEST HAUNCH CONNECTION

NORTH WALL.

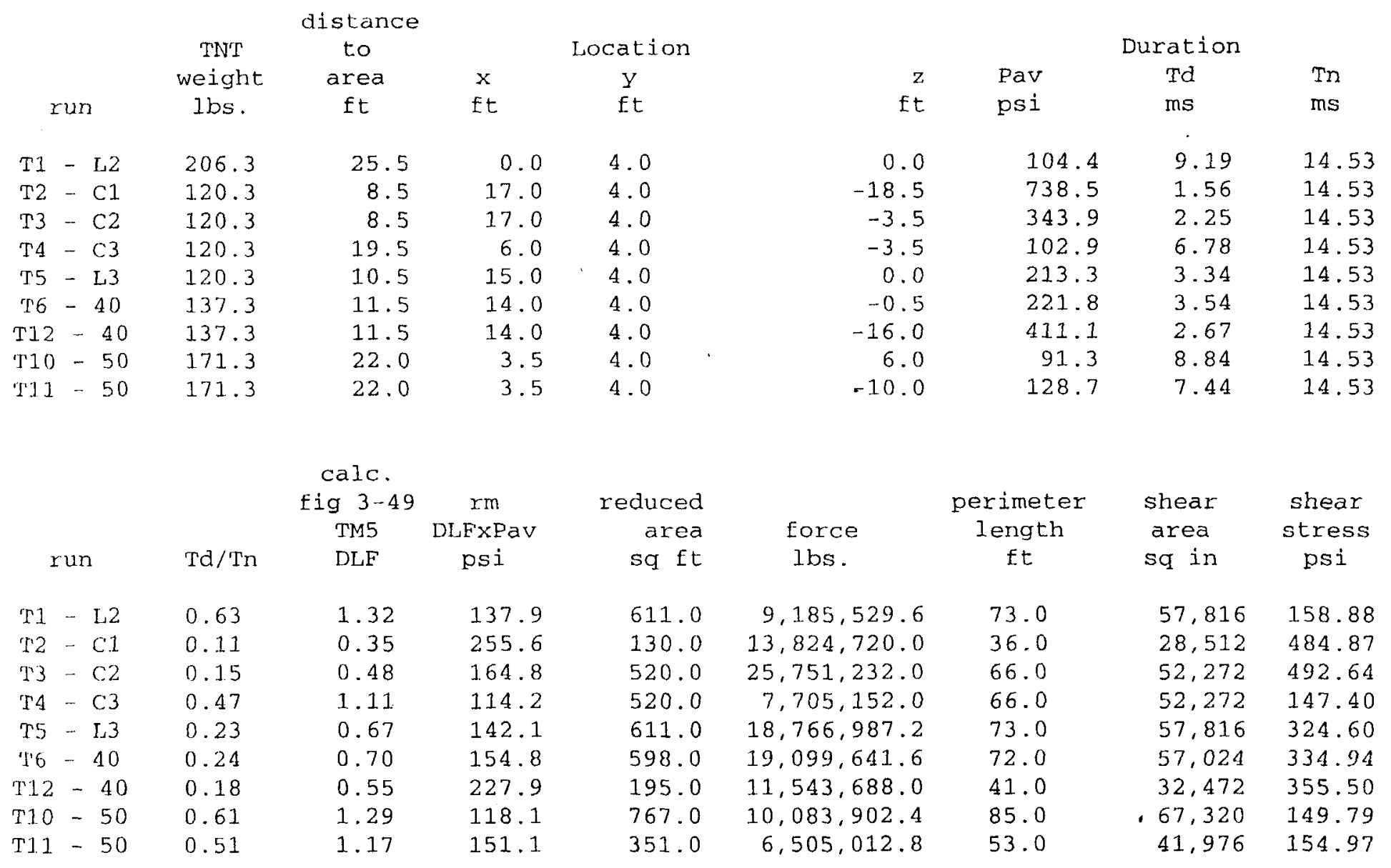




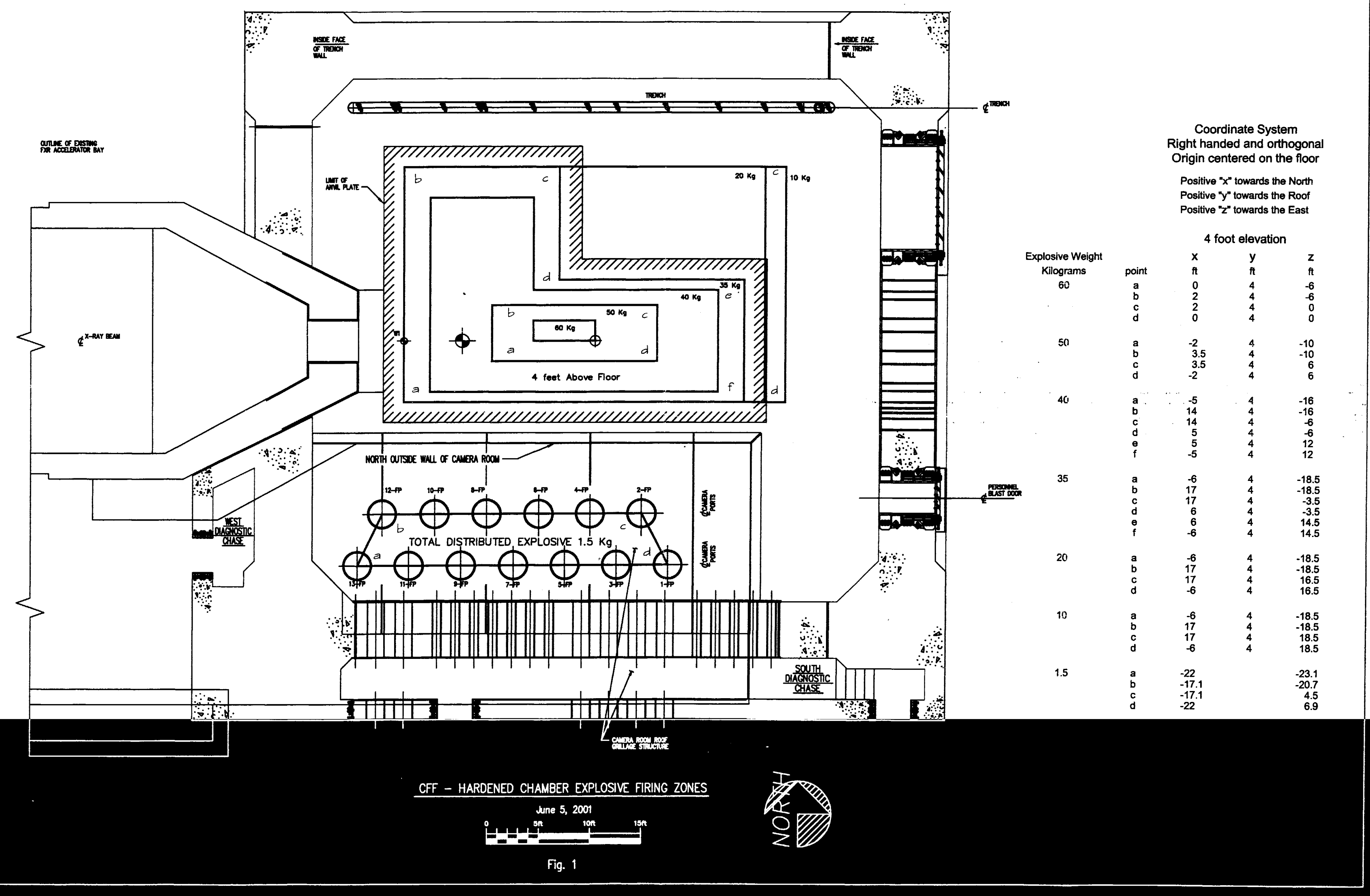




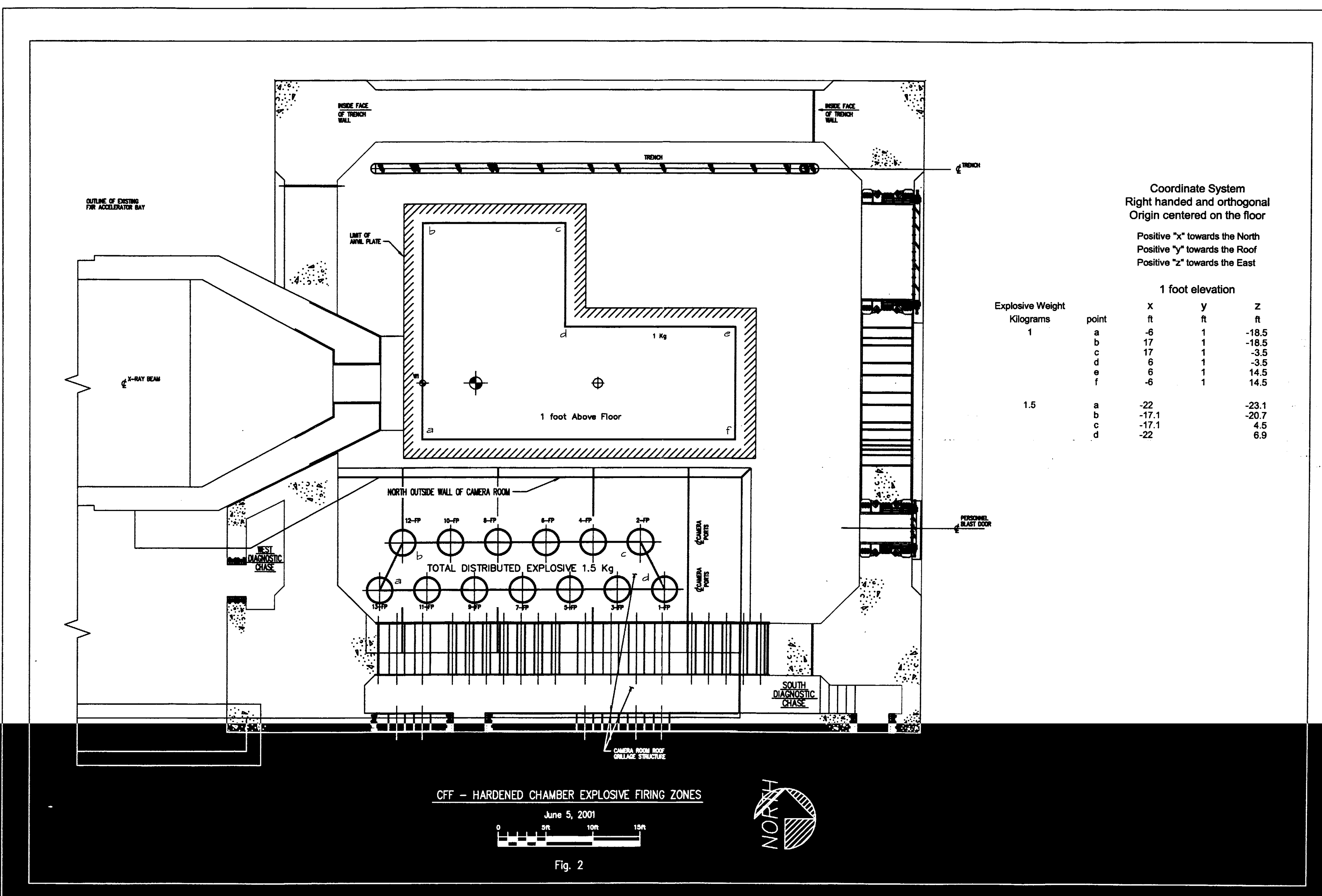




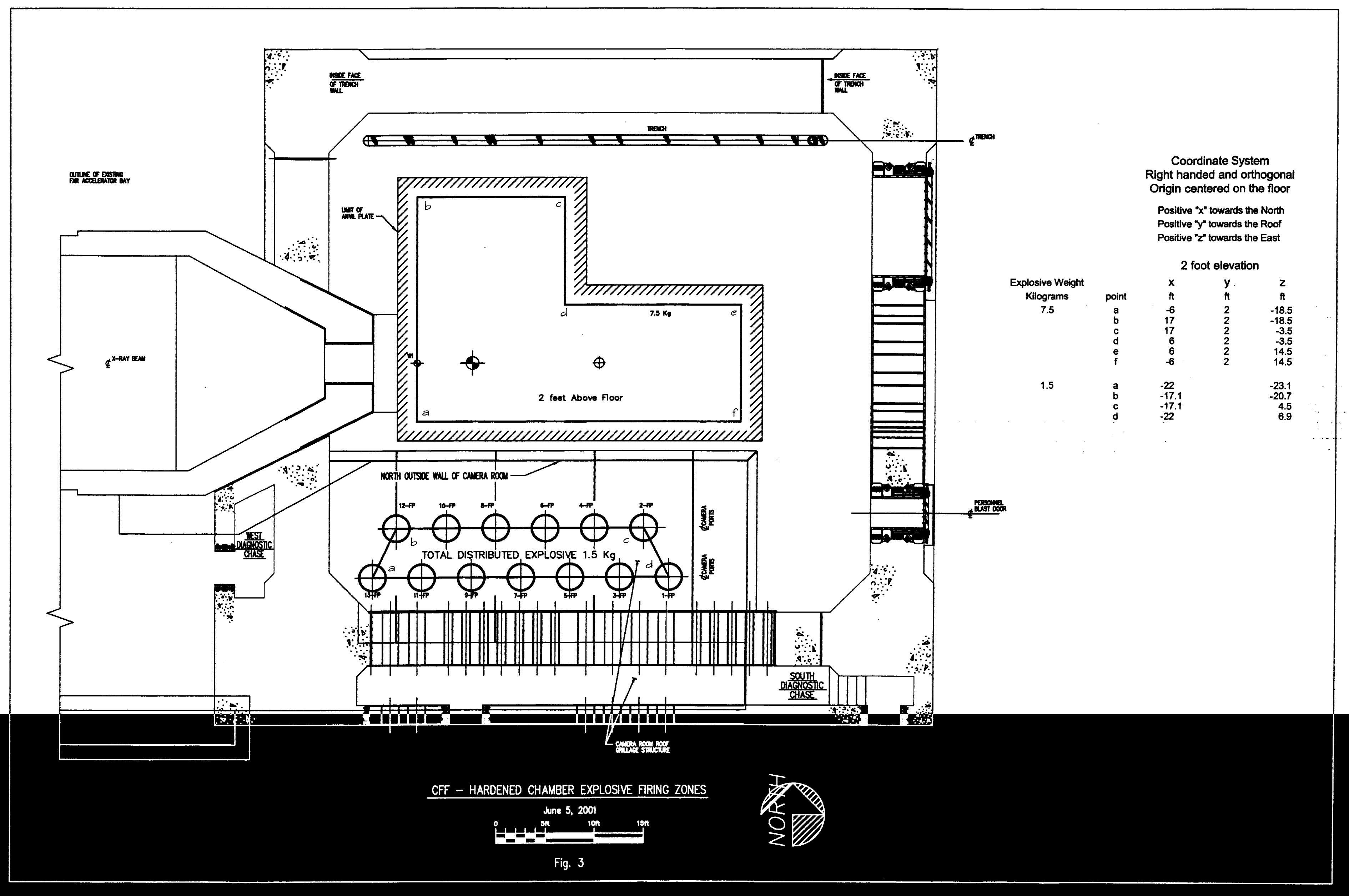




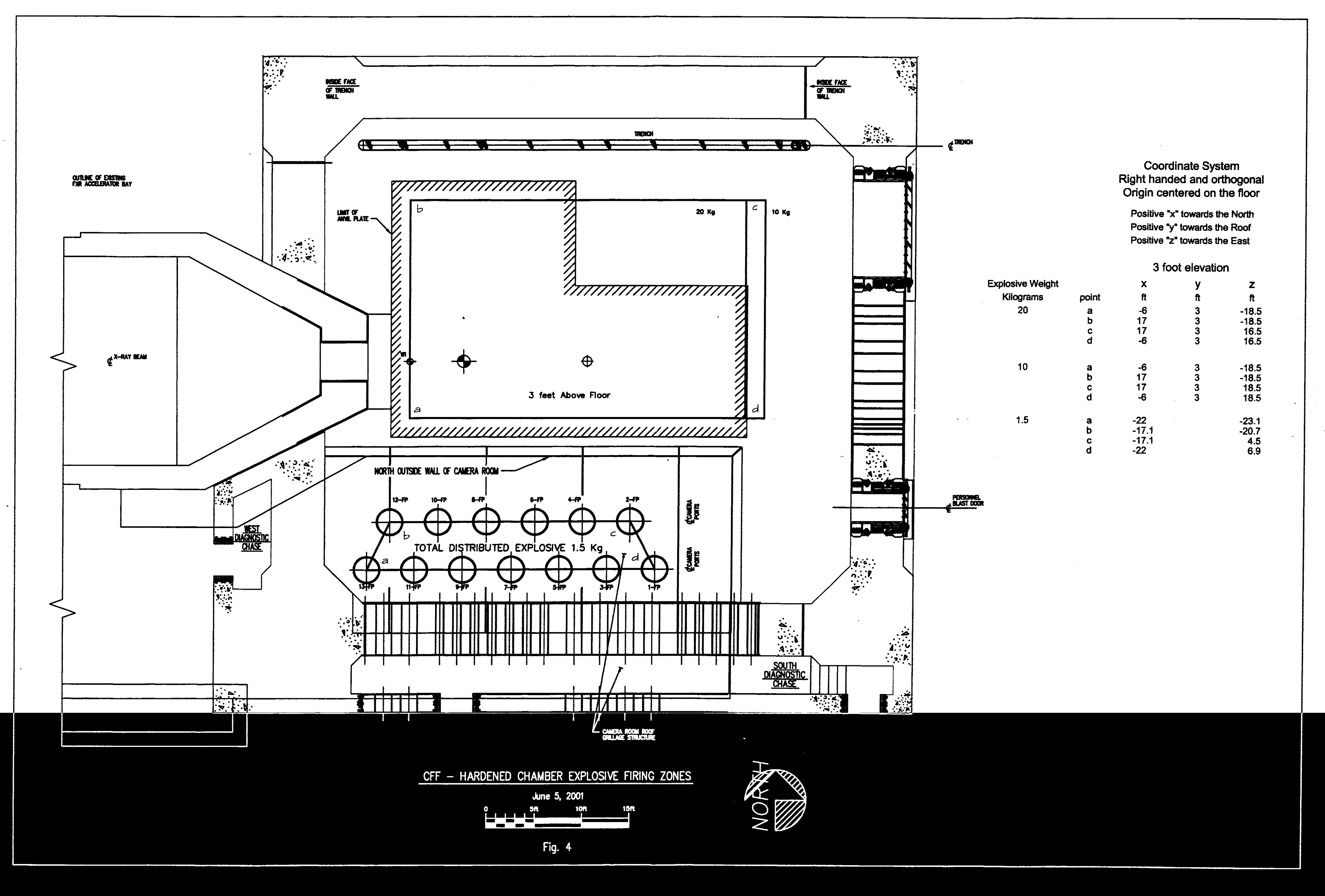




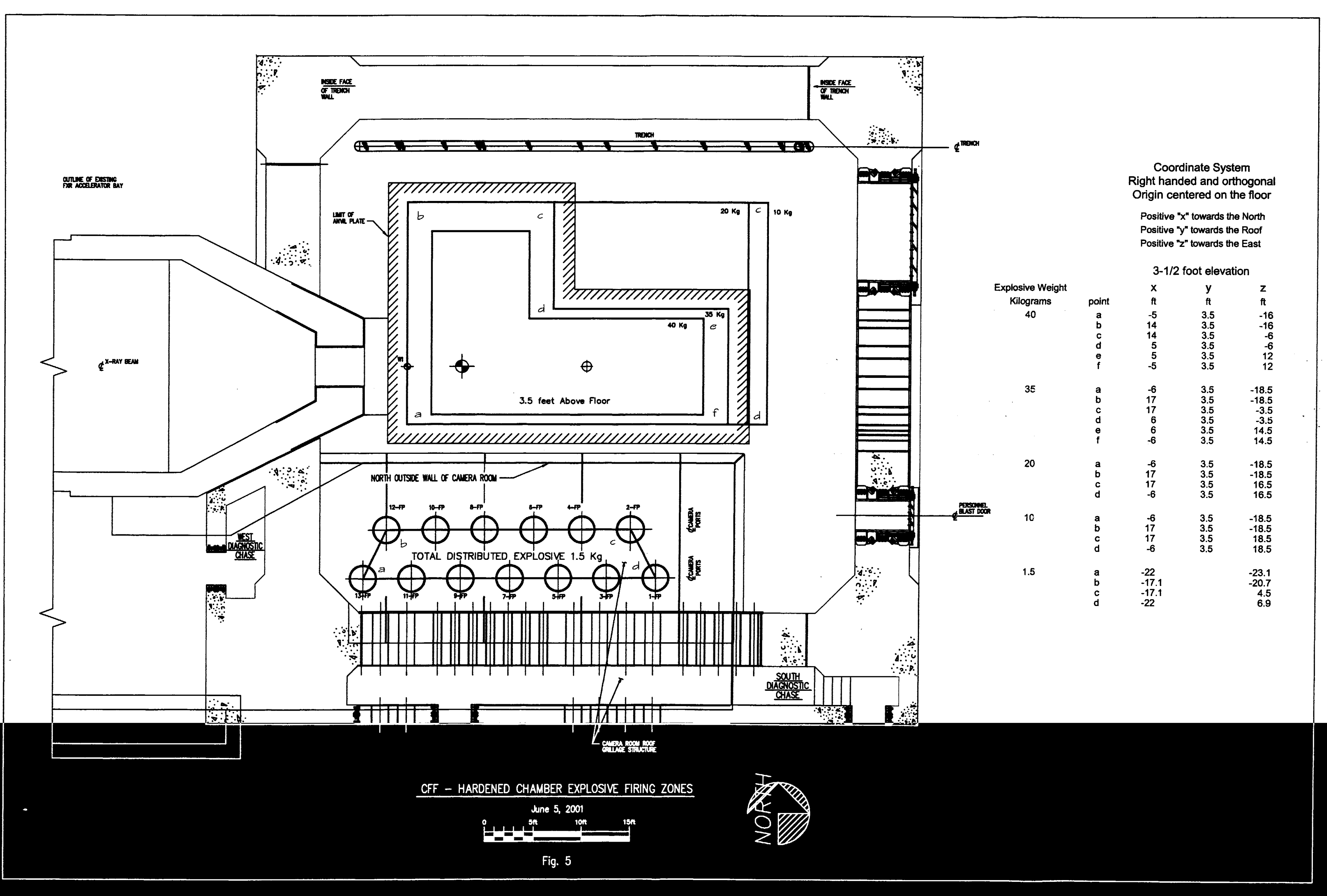




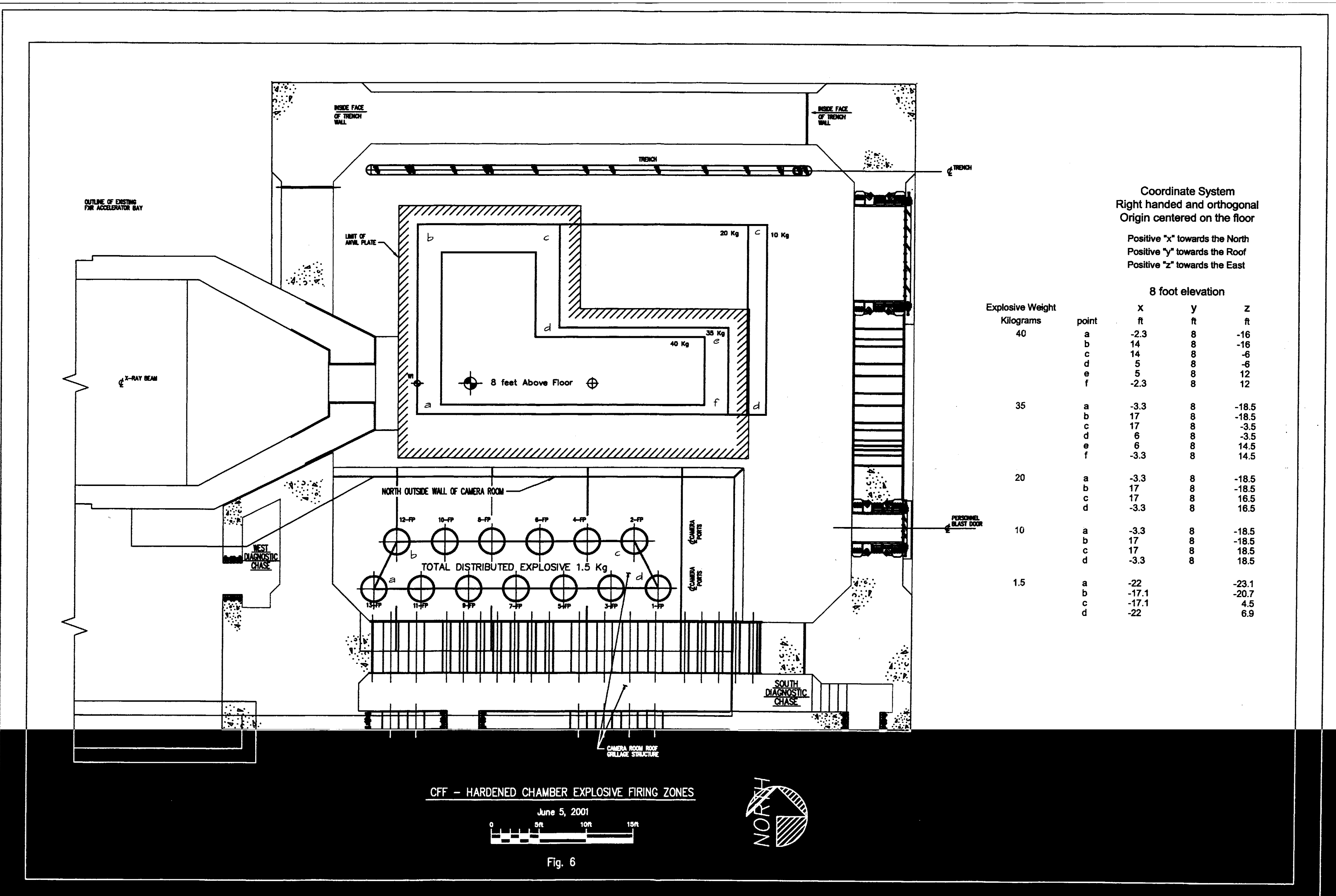




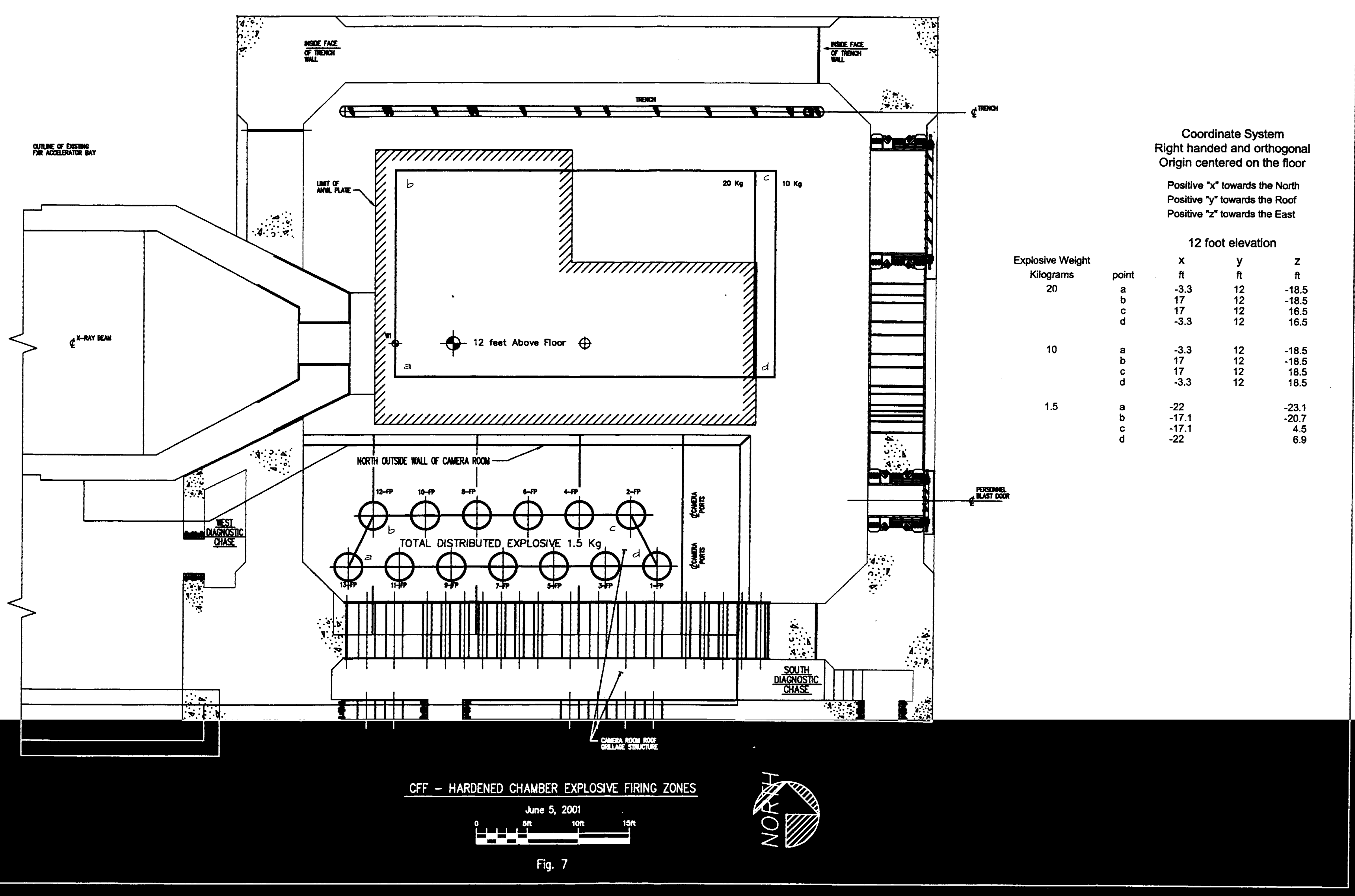

